\title{
Gonadotropin-Releasing Hormone-Induced Elevation of Serum hCG in Choriocarcinoma: A Case Report
}

\author{
MADOKA FURUHASHI, YUKI MIYABE, YOSHINARI KATSUMATA, \\ HIROYUKI ODA, AND NOBUAKI IMAI \\ Department of Obstetrics and Gynecology, Handa City Hospital, Handa 475-8599, Japan
}

\begin{abstract}
We evaluated the effect of $\mathrm{GnRH}$ on the serum hCG level in gestational trophoblastic disease (GTD). Five patients with GTD were studied. Three patients had hydatidiform mole (two complete and one partial mole) and two had choriocarcinoma. Blood samples were collected immediately before and 30, $60 \mathrm{~min}$ after the $100 \mu \mathrm{g} \mathrm{GnRH}$ iv injection, followed by hCG assay. Only one case of choriocarcinoma demonstrated an hCG increase after intravenous administration of GnRH (positive GnRH test). In that case, the hCG level dropped to the normal range after eight cycles of chemotherapy but the GnRH test was still positive, suggesting the existence of viable cancer cells. Since the GnRH test became negative, no increase in hCG has been observed, indicating that the patient achieved complete remission. Although a positive GnRH test is not common in GTD, GnRH test before treatment might be useful to find a positive case where the test can be repeated to determine complete remission and the time when the chemotherapy may be discontinued.
\end{abstract}

Key words: Gestational trophoblastic disease, GnRH, hCG, Chemotherapy

(Endocrine Journal 45: 585-590, 1998)

GESTATIONAL trophoblastic disease (GTD) comprises a group of conditions derived from the trophoblast and includes complete and partial hydatidiform mole, gestational choriocarcinoma and placental site trophoblastic tumor. They have the following unusual characteristics: 1) These conditions are very rare and there are regional and ethnic differences in the incidence of hydatidiform mole and choriocarcinoma [1]. The incidence of hydatidiform mole in Japan is about two per 1,000 pregnancies [2] and twice that seen in Europe and the USA. In an Hawaiian study [3], the rates were higher in the Oriental than in the Caucasian group. Although the incidence of choriocarcinoma is higher in Asia than in the USA, it is decreasing

Received: October 30, 1997

Accepted: March 27, 1998

Correspondence to: Dr. Madoka FURUHASHI, Department of Obstetrics and Gynecology, Handa City Hospital, 2-29 Toyo-cho, Handa, Aichi 475-8599, Japan owing to the strict management and follow-up of molar patients [4]. 2) GTD is unique in that hCG is consistently produced when an active tumor is present. Measurement of this hormone is useful for establishing the diagnosis, determining the response to chemotherapy, defining complete remission and detecting rare recurrences. 3) GTD is also unique in its chemosensitivity. Since the introduction of methotrexate (MTX) therapy into the treatment of GTD in 1956 [5], trophoblastic tumors have become one of the most curable forms of malignancy. Preferable remission rates have been reported for patients with nonmetastatic disease and for those with low-risk and mediumrisk metastatic disease $[6,7]$. Even in the high-risk group, combination chemotherapy with etoposide, MTX, actinomycin D, cyclophosphamide and vincristine has been shown to induce remission in about $70 \%$ of patients [8, 9]. After the patients show negative hCG levels, additional chemotherapy must be administered to reduce the risk of a relapse, 
but no consensus has been achieved concerning the times of chemotherapy.

The regulation of synthesis and secretion of hCG has been extensively investigated. The human placenta contains GnRH [10] and specific GnRH binding sites [11], and its dose-dependent effect on hCG production in placenta and GTD in vitro has been well documented [12-15]. Recently Iwashita et al. [16] reported that GnRH stimulates the release of hCG from the placenta in vivo, although the responsiveness depends on gestational age and the implantation site, but few data in vivo on GnRH-induced alterations in the secretion of hCG has been shown in patients with GTD.

In the present study, the effect of GnRH on the serum hCG level was examined in five patients with GTD to investigate whether the hCG secretion is regulated by $\mathrm{GnRH}$ and, if it is, the time when chemotherapy is discontinued.

\section{Subjects and Methods}

\section{Subjects}

Three patients with hydatidiform mole (two complete and one partial mole) and two patients with choriocarcinoma were studied. The diagnosis was confirmed by histological examination. The aim of this study was explained and informed consent was obtained from the patients. GnRH test was performed before starting the treatment in all cases except case 5 where it was carried out periodically during the course of chemotherapy. Individual clinical and hormonal data are summarized in Table 1.

\section{GnRH stimulation and hormone assay}

GnRH test was performed with an iv bolus injection of $100 \mu \mathrm{g}$ GnRH (Tanabe Pharmaceutical Co., Osaka, Japan) in $10 \mathrm{ml}$ of saline. Blood samples were collected immediately before and 30,60 min after the $\mathrm{GnRH}$ injection. The serum was kept frozen at $-20^{\circ} \mathrm{C}$ until assay.

The SRL hCG enzyme immunoassay kit (SRL Inc., Tokyo, Japan), which detects holo-hCG, was used for the assay of serum hCG. This is a sandwich assay with monoclonal antibody to the $\mathrm{C}$-terminus of the hCG $\beta$-subunit and peroxidaselabeled monoclonal antibody to $\alpha$-subunit. According to the manufacturer's report, the lower limit of the assay level is $0.4 \mathrm{mIU} / \mathrm{ml}$. Because the coefficient of variation of intra- and interassay variation is below $15 \%$, an increase in the hCG level of more than $30 \%$ was defined as a positive response to $\mathrm{GnRH}$. Cross-reactivity with $\mathrm{LH}$ is $0.008 \%$. The normal range in women is less than

Table 1. Summary of clinical features

\begin{tabular}{|c|c|c|c|c|c|c|c|c|}
\hline $\begin{array}{l}\text { case } \\
\text { No. }\end{array}$ & $\begin{array}{l}\text { age } \\
\text { (yr) }\end{array}$ & gravida & para & $\begin{array}{c}\mathrm{hCG}^{\mathrm{a}} \\
(\mathrm{mIU} / \mathrm{ml})\end{array}$ & GnRH test ${ }^{b}$ & $\begin{array}{l}\text { antecedent } \\
\text { pregnancy }\end{array}$ & metastasis & therapy \\
\hline \multicolumn{9}{|c|}{ complete hydatidiform mole } \\
\hline 1 & 49 & 4 & 2 & 79,000 & negative & TA & $(-)$ & $\mathrm{D} \& \mathrm{C}, \mathrm{STH}$ \\
\hline 2 & 34 & 6 & 3 & 690,000 & negative & TA & $(-)$ & D\&C \\
\hline \multicolumn{9}{|c|}{ partial hydatidiform mole } \\
\hline 3 & 33 & 0 & 0 & 75,000 & negative & $(-)$ & $(-)$ & $\mathrm{D} \& \mathrm{C}$ \\
\hline \multicolumn{9}{|c|}{ choriocarcinoma } \\
\hline 4 & 45 & 7 & 3 & 300,000 & negative & SA & $(-)$ & $\begin{array}{c}\text { STH, BSO } \\
\text { chemotherapy }\end{array}$ \\
\hline 5 & 53 & 4 & 3 & 7,500 & positive & TA & lung & $\begin{array}{c}\text { STH, BSO } \\
\text { chemotherapy }\end{array}$ \\
\hline
\end{tabular}


$0.7 \mathrm{mIU} / \mathrm{ml}$. LH in the serum was determined with the Spac-S LH kit (Daiichi Radioisotope Laboratory, Tokyo, Japan) which uses an immunoradiometric assay method and two monoclonal antibodies that react with the $\beta$-subunit and intact dimer, respectively.

\section{History of case 5}

In case 5 , because there was an increase in serum hCG after intravenous administration of GnRH, we reviewed the case in detail.

A 53-year-old woman, gravida 4, para 3, presented with a history of irregular genital bleeding for six months and lower abdominal pain for two weeks. Menopause was seen at 50 years of age. The preceding pregnancy was a therapeutic abortion at 34 years of age. There was no pathological examination of the tissue obtained from the aborted fetus. Vaginal examination and pelvic ultrasound showed a double fist-sized uterine mass. Endometrial and cervical smear were negative. Routine examination on admission revealed leukocytosis (white blood cell count $10,000 / \mathrm{mm}^{3}$ ), but tumor markers such as cancerrelated antigen 125 and carcinoembryonic antigen were in the normal range except for a slight increase in lactate dehydrogenase $(418 \mathrm{U} / l)$.

An abdominal hysterectomy with bilateral salpingo-oophorectomy was carried out. Histology of the uterus showed that the tumor consisted of cytotrophoblast and syncytiotrophoblast cells with a large necrosis area. Immunohistochemical study was positive for hCG and confirmed the diagnosis of choriocarcinoma. The hCG level in the serum collected before operation and stored at $-20^{\circ} \mathrm{C}$ was $7,500 \mathrm{mIU} / \mathrm{ml}$. Chest X-ray and CT scan showed a $1 \times 1 \mathrm{~cm}$ nodule in the right lung.

Chemotherapy consisting of actinomycin D (0.5 $\mathrm{mg}$ iv) and methotrexate ( $20 \mathrm{mg} \mathrm{im}$ ) on days $1-4$ inclusive was started concomitantly. After four cycles, the therapy was changed to an EP regimen (etoposide $100 \mathrm{mg}$ iv and cisplatin $15 \mathrm{mg}$ iv on days 1-5 inclusive) because adverse effects such as liver dysfunction and oral mucosal ulceration were observed and the hCG level plateaued. At 20 months since the last chemotherapy, the patient is well with undetectable hCG level and no evidence of disease.

\section{Results}

Three patients with hydatidiform mole (cases 13 ), revealed no increase in serum hCG due to GnRH (Table 1). Of two patients with choriocarcinoma, in only one (case 5) was hCG increased after intravenous administration of $\mathrm{GnRH}$; so we followed up this case with $\mathrm{GnRH}$ test during the course of the chemotherapy (Table 2). The serum hCG level decreased as the chemotherapy was repeated. After the fourth cycle of EP, the hCG level was in the normal range $(<0.7 \mathrm{mIU} / \mathrm{ml})$, whereas it was still high after the administration of GnRH. The positive GnRH test suggested that active cancer cells still existed. After the fifth EP, no increase in hCG caused by GnRH was demonstrated, and the patient was therefore regarded as in complete remission.

\section{Discussion}

Although currently available treatment can cure patients with choriocarcinoma even in the high risk group, the time when chemotherapy can be discontinued is still a clinical matter for discussion. A temporary rise in the hCG level after the administration of anti-tumor drugs is observed in some cases where a negative hCG titer has been achieved. This phenomenon is called cellular response. A Nagoya University group (Japan) regards the absence of cellular response as complete remission [17], but the fact that there is no cellular response does not always assure complete remission because small number of active cells cannot produce a detectable level of hCG. Usually additional chemotherapy is carried out to prevent recurrent GTD after achieving negative hCG levels [6]. The number of maintenance chemotherapy cycles should be minimized but guarantee remission. In case 5, the hCG level fell to the normal range after the fourth EP but the $\mathrm{GnRH}$ test was still positive (Table 2). The GARH test first became negative just before the sixth EP. No increase in serum hCG even after GnRH administration has been observed since then. This case clearly shows that even if the serum hCG level is normal, there still exist active cells which result in a positive $\mathrm{GnRH}$ test, so that it is conceivable that the $\mathrm{GnRH}$ 
Table 2. GnRH test during the course of chemotherapy in case 5

\begin{tabular}{|c|c|c|c|c|c|c|}
\hline \multirow[b]{2}{*}{ Date } & \multicolumn{3}{|c|}{$\mathrm{hCG}(\mathrm{mIU} / \mathrm{ml})$} & \multicolumn{3}{|c|}{$\mathrm{LH}(\mathrm{mIU} / \mathrm{ml})$} \\
\hline & basal & $30 \mathrm{~min}$ & $60 \mathrm{~min}$ & basal & $30 \mathrm{~min}$ & $60 \mathrm{~min}$ \\
\hline \multicolumn{7}{|l|}{ (chemotherapy: MA) } \\
\hline $\begin{array}{l}\text { 07/10/95 } \\
\text { (chemotherapy: A) }\end{array}$ & 2.8 & 4.6 & 4.3 & 49 & 240 & 230 \\
\hline $\begin{array}{l}\text { 07/24/95 } \\
\text { (chemotherapy: MA) }\end{array}$ & 2.3 & 3.3 & 3.6 & & & \\
\hline $\begin{array}{l}\text { 08/07/95 } \\
\text { (chemotherapy: MA) } \\
\text { (chemotherapy: EP) }\end{array}$ & 2.1 & 2.6 & 3.2 & & & \\
\hline $\begin{array}{l}\text { 09/11/95 } \\
\text { (chemotherapy: EP) }\end{array}$ & 1.5 & 2.0 & 2.5 & 50 & 220 & 320 \\
\hline $\begin{array}{l}\text { 10/02/95 } \\
\text { (chemotherapy: EP) }\end{array}$ & 1.0 & 1.5 & 1.8 & & & \\
\hline $10 / 16 / 95$ & 1.0 & 1.5 & 1.6 & & & \\
\hline $\begin{array}{l}\text { 10/30/95 } \\
\text { (chemotherapy: EP) }\end{array}$ & 0.8 & 1.1 & 1.3 & & & \\
\hline $11 / 13 / 95$ & 0.6 & 0.9 & 1.2 & & & \\
\hline $\begin{array}{l}\text { 11/27/95 } \\
\text { (chemotherapy: EP) }\end{array}$ & 0.7 & 1.0 & 1.2 & & & \\
\hline $12 / 11 / 95$ & 0.6 & 0.8 & 0.9 & & & \\
\hline $12 / 25 / 95$ & $<0.4$ & 0.6 & 0.8 & & & \\
\hline $\begin{array}{l}\text { 01/22/96 } \\
\text { (chemotherapy: EP) } \\
\text { (chemotherapy: EP) }\end{array}$ & 0.5 & 0.5 & 0.6 & 27 & 100 & 130 \\
\hline $03 / 11 / 96$ & $<0.4$ & $<0.4$ & $<0.4$ & & & \\
\hline
\end{tabular}

M, methotrexate; A, actinomycin D; E, etoposide; $\mathrm{P}$, cisplatin.

test is useful in determining complete remission and the time when the chemotherapy is to be discontinued. The patient received three cycles of chemotherapy beyond the first negative hCG level because we did not know when the patient should be judged to be in complete remission. Considering the negative GnRH test in retrospect, the last two cycles of chemotherapy might not be necessary.

The issue which should be noted is that not every case of GTD shows a positive GnRH test. In our cases, no response was observed in hydatidiform mole. Because the number of cases in our study was limited, further investigation will be required to clarify whether the same result is obtained in other cases. Basic research will also be necessary to determine whether there exists a $\mathrm{GnRH}$ receptor and $\mathrm{GnRH}$ regulates $\mathrm{hCG}$ secretion in hydatidiform mole. hCG secretion caused by GnRH stimulation has been shown in vitro by using choriocarcinoma cell lines $[15,18]$, so that it was considerably anticipated that $\mathrm{GnRH}$ injection increased the serum hCG level in patients with choriocarcinoma, but one of two patients (case 4) did not have a positive $\mathrm{GnRH}$ test. This indicates that a positive $\mathrm{GnRH}$ test is not specific in choriocarcinoma among GTD.

In pregnancies, the implantation site affected the response of hCG to GnRH [16]. Patients with tubal pregnancy did not respond to $\mathrm{GnRH}$, in contrast to normal pregnancy or missed abortion where a fertilized egg was implanted in the uterus. In two cases of choriocarcinoma, case 5 had metastasis in the lung, but no metastasis was demonstrated in case 4. When GnRH test was first carried out in case 5, hysterectomy was already done and only the lung lesion remained. The different response to $\mathrm{GnRH}$ in cases 4 and 5 may be due to the different location of choriocarcinoma cells. Alternatively, the character of the cells is different as seen in the hCG level (Table 1).

Because the increase in hCG due to GnRH was small in absolute value during the course of chemotherapy in case 5 , it may be taken as the allowable margin of error or due to the detection of LH. As mentioned in Subjects and Methods, 
the kit used for measuring hCG detects as low as $0.4 \mathrm{mIU} / \mathrm{ml}$ of holo-hCG and cross-reactivity with LH is only $0.008 \%$. Moreover, no increase in serum hCG was observed in January, whereas LH markedly increased following GnRH administration (Table 2). Although we did not confirm that the infusion of saline alone did not alter hCG levels, it is unlikely because GnRH test did not show a change in hCG levels in January and March, so that the change in the hCG level is not due to the $\mathrm{LH}$ increase or the effect of saline but accurately reflects the increase in serum hCG and the response to GnRH.

With respect to hCG storage in granules in the cells, it depends on the cell type. When hCG was expressed in Chinese hamster ovary cells which do not contain granules, it was secreted constitutively, whereas it was stored and secreted in the regulatory pathway in $\mathrm{GH}_{3}$ cells which contain storage granules [19]. This means that hCG has the ability to be stored if the cell has storage granules. No large dense-core storage granules have been identified in placenta and choriocarcinoma cell lines [20], but stimulation of hCG release by $\mathrm{GnRH}$ and $\mathrm{KCl}$ from choriocarcinoma cells [15] and an increase in serum hCG shortly after GnRH administration in pregnant women [16] support the idea that there may be a small number of granules in placenta and malignant trophoblastic tissues.

Case 5 is unusual in age and the interval since the last pregnancy. Although choriocarcinoma 6 years after menopause and 29 years after the last pregnancy was recently reported [21], GTD in postmenopausal women is extremely rare. Tsukamoto et al. [22] reported on 50 cases of GTD at age 50 or older. Three were postmenopause and in two there had been an interval of 15 years or more since the last pregnancy. In such cases, whether it is gestational or nongestational is of interest. To differentiate gestational from nongestational tumors, the identification of paternal alleles in the tumor tissue on the basis of restriction fragment length polymorphism (RFLP) has been proved useful [23, 24]. Although RFLP of DNA was not examined in case 5 , it seems to be gestational because the lesion was observed in only the uterus and the lung which is the most common site for metastasis of GTD [25].

In summary, serum hCG increase due to GnRH is not universal in GTD. In cases of positive GnRH test, however, GnRH test might be useful in determining complete remission and the time when the chemotherapy may be discontinued. Patients may therefore benefit by undergoing the most minimal but effective chemotherapy and by avoiding unnecessary ones.

\section{Acknowledgements}

We thank the medical staff of the Department of Obstetrics and Gynecology for their support.

\section{References}

1. Palmer JR (1994) Advances in the epidemiology of gestational trophoblastic disease. J Reprod Med 39: 155-162.

2. Takeuchi S (1987) Incidence of gestational trophoblastic disease by regional registration in Japan. Hum Reprod 2: 729-734.

3. McCorriston CC (1968) Racial incidence of hydatidiform mole: A study in a contained polyracial community. Am J Obstet Gynecol 101: 377382.

4. Ishizuka N, Tomoda $Y$, Kaseki S, Goto S, Ishizuka T, Furuhashi Y (1990) Incidence of trophoblastic disease. In: Ishizuka N, Tomoda Y (eds) Gestational Trophoblastic Disease. The University of Nagoya Press, Nagoya, 1-8.

5. Li MC, Hertz R, Spencer DB (1956) Effect of methotrexate therapy upon choriocarcinoma and chorioadenoma. Proc Soc Exp Biol Med 93: 361-366.

6. Mutch DG, Soper JT, Babcock CJ, Clarke-Pearson DL, Hammond CB (1990) Recurrent gestational trophoblastic disease: Experience of the southeastern regional trophoblastic disease center. Cancer 66: 978-982.

7. Ayhan $\ddot{A}$, Yapar EG, Deren Ö, Kişnişçi H (1992) Remission rates and significance of prognostic factors in gestational trophoblastic tumors. J Reprod Med 37: 461-465.

8. Soper JT, Evans AC, Clarke-Pearson DL, Berchuck A, Rodriguez G, Hammond CB (1994) Alternating weekly chemotherapy with etoposide-methotrexatedactinomycin/cyclophosphamide-vincristine for high-risk gestational trophoblastic disease. Obstet 
Gynecol 83: 113-117.

9. Berkowitz RS, Goldstein DP (1995) Gestational trophoblastic disease. Cancer 76: 2079-2085.

10. Petraglia F, Volpe A, Genazzani AR, Rivier J, Sawchenko PE, Vale W (1990) Neuroendocrinology of the human placenta. Front Neuroendocrinol 11: 637.

11. Bramley TA, McPhie CA, Menzies GS (1992) Human placental gonadotrophin-releasing hormone (GnRH) binding sites: I. Characterization, properties and ligand specificity. Placenta 13: 555-581.

12. Kim SJ, Namkoong SE, Lee JW, Jung JK, Kang BC, Park JS (1987) Response of human chorionic gonadotrophin to luteinizing hormone-releasing hormone stimulation in the culture media of normal human placenta, choriocarcinoma cell lines, and in the serum of patients with gestational trophoblastic disease. Placenta 8: 257-264.

13. Currie WD, Steele GL, Yuen BH, Kordon C, Gautron JP, Leung PCK (1992) Luteinizing hormonereleasing hormone (LHRH)- and (Hydroxyproline $\left.{ }^{9}\right)$ LHRH-stimulated human chorionic gonadotropin secretion from perifused first trimester placental cells. Endocrinology 130: 2871-2876.

14. Szilágyi A, Benz R, Rossmanith WG (1992) The human first-term placenta in vitro: Regulation of hCG secretion by GnRH and its antagonist. Gynecol Endocrinol 6: 293-300.

15. Ertl T, Török A, Bódis J, Pflieger S, Zwirner M, Hanf V, Tinneberg HR (1993) Spontaneous and gonadotropin-releasing hormone induced human chorionic gonadotropin release from superfused JAR choriocarcinoma cells. Arch Gynecol Obstet 253: 43-49.

16. Iwashita M, Kudo Y, Shinozaki Y, Takeda Y (1993) Gonadotropin-releasing hormone increases serum human chorionic gonadotropin in pregnant women.
Endocr J 40: 539-544.

17. Hirokawa K, Tomoda Y, Kaseki S, Ishizuka T, Nishikawa Y, Goto S (1986) Recurrence of invasive moles and choriocarcinomas. Asia-Oceania J Obstet Gynaecol 12: 11-20.

18. Shi LY, Zhang ZW, Li WX (1994) Regulation of human chorionic gonadotropin secretion and messenger ribonucleic acid levels by follistatin in the NUCC-3 choriocarcinoma cell line. Endocrinology 134: 2431-2437.

19. Bielinska M, Rzymkiewicz D, Boime I (1994) Human luteinizing hormone and chorionic gonadotropin are targeted to a regulated secretory pathway in $\mathrm{GH}_{3}$ cells. Mol Endocrinol 8: 919-928.

20. Suemizu H, Osamura Y, Watanabe K (1988) Ultrastructural localization of hCG and subunits in the human placenta and choriocarcinoma cell lines: Morphological approach to secretory pathway. Acta Histochem Cytochem 21: 265-271.

21. Massenkeil G, Crombach G, Dominik S, DeBruyne F, Nitz U, Krüssel J, Bender HG (1996) Metastatic choriocarcinoma in a postmenopausal woman. Gynecol Oncol 61: 432-437.

22. Tsukamoto $\mathrm{N}$, Iwasaka $\mathrm{T}$, Kashimura $\mathrm{Y}$, Uchino $\mathrm{H}$, Kashimura M, Matsuyama T (1985) Gestational trophoblastic disease in women aged 50 or more. Gynecol Oncol 20: 53-61.

23. Fisher RA, Newlands ES, Jeffreys AJ, Boxer GM, Begent RHJ, Rustin GJS, Bagshawe KD (1992) Gestational and nongestational trophoblastic tumors distinguished by DNA analysis. Cancer 69: 839-845.

24. Arima $T$, Imamura $T$, Amada $S$, Tsuneyoshi $M$, Wake N (1994) Genetic origin of malignant trophoblastic neoplasms. Cancer Genet Cytogenet 73: 95-102.

25. Berkowitz RS, Goldstein DP (1996) Chorionic tumors. N Engl J Med 335: 1740-1748. 